$12-21-2021$

\title{
Ongoing Genocides and the Need for Healing: The Cases of Native and African Americans
}

\author{
Benjamin P. Bowser \\ California State University, East Bay \\ Carl O. Word \\ Research Psychologist \\ Kate Shaw \\ Private Practice
}

Follow this and additional works at: https://digitalcommons.usf.edu/gsp

\section{Recommended Citation}

Bowser, Benjamin P.; Word, Carl O.; and Shaw, Kate (2021) "Ongoing Genocides and the Need for Healing: The Cases of Native and African Americans," Genocide Studies and Prevention: An International Journal: Vol. 15: Iss. 3: 83-99.

DOI:

https://doi.org/10.5038/1911-9933.15.3.1785

Available at: https://digitalcommons.usf.edu/gsp/vol15/iss3/11

This Articles is brought to you for free and open access by the Open Access Journals at Digital Commons @ University of South Florida. It has been accepted for inclusion in Genocide Studies and Prevention: An International Journal by an authorized editor of Digital Commons @ University of South Florida. For more information, please contact digitalcommons@usf.edu. 


\section{Ongoing Genocides and the Need for Healing: The Cases of Native and African Americans}

\section{Acknowledgements}

We wish to acknowledge the support of the UNESCO Slave Route Project, and Aimé Charles-Nicolas of the Université des Antilles and University Hospital of Martinique. 


\title{
Ongoing Genocides and the Need for Healing: The Cases of Native and African Americans
}

\author{
Benjamin P. Bowser \\ California State University, East Bay \\ Hayward, California, U.S.A. \\ Carl O. Word \\ Research Psychologist \\ San Leandro, California, U.S.A. \\ Kate Shaw \\ Private Practice \\ Alexandria, Virginia, U.S.A.
}

\section{Introduction}

In the US, racism and its traumatic outcomes are the most significant and far-reaching legacy of the slave trade, slavery, and the elimination of Native peoples. By 1865, the African slave trade and slavery were ended as social institutions. The last Indian resistance occurred in 1890 just before the Wounded Knee massacre. What did not end were the attitudes, beliefs, and values that made slavery an intrinsic part of Southern life for over two hundred years, and that made the killing of Indian people necessary to settle the nation. A consequence is the treatment of freedmen and Indians as less than humans continues into the present with all their traumatic illeffects. One of the legacies of slavery's beliefs, intrinsic to American racism, is the now scientifically discredited idea of races as biologically and anthropologically meaningful and distinct entities. ${ }^{1}$ Despite being thoroughly discredited, there is still an almost universal racial self-identification of Americans as White, Black, Asian, and Indian; belief in races is as real today as it was in 1840. These identities were invented by Virginia and North Carolina colonial legislatures to justify and sustain slavery. ${ }^{2}$ The presumptive inferiority of Black and Native Americans and the superiority of White Americans is slavery's second legacy which frames contemporary attitudes and the treatment of African and Native Americans. In combination, these two historical beliefs made possible the selling and buying of humans as chattel, the justification for taking Indian lands, and are now at the core of the nation's contemporary racism.

Racism does not originate nor is it sustained by individual shortcoming. After generations of belief and practice, racism's core presumptions are expressed in three ways. ${ }^{3}$ First, racial inferiority and superiority (hierarchy) are the mental blueprints of expected outcomes regarding race-racism is a cultural phenomenon. Second, the presumptions of racial hierarchy, embedded in culture, are actualized institutionally in education, housing, employment, and the application of the law and police practices-institutional racism. Third, consciously or unconsciously, individuals act out their cultural beliefs in racial hierarchy by maintaining racist institutional practices and outcomes-individual racism. A consistent result of these three expressions of racism is social and economic inequality by race across generations. Other results are the psychological costs of contemporary racism to all involved in

\footnotetext{
1 American Anthropological Association, "AAA Statement on Race," American Association of Physical Anthropologists 101 (1996), 569-570

2 Theodore W. Allen, The Invention of the White Race (London: Verso, 1994).

3 Stokely Carmichael and Charles Hamilton, Black Power: The Politics of Liberation in America (New York: Random House, 1967).
}

Benjamin P. Bowser, Carl O. Word, and Kate Shaw. "Ongoing Genocides and the Need for Healing: The Cases of Native and African Americans." Genocide Studies and Prevention 15, no. 3, 83-99. https://doi.org/ 10.5038/1911-9933.15.3.1785.

(C) 2021 Genocide Studies and Prevention. 
trauma and compromised health and well-being. ${ }^{4}$ These are added to the still unresolved historical traumas of slavery and Indian elimination.

In this essay, we wish to demonstrate that the historical beliefs that made genocide possible in the US are the very same beliefs sustaining contemporary racism. Our first objective is to establish that the African slave trade, slavery, and the elimination of Native peoples in the US are acts of genocide and are distinct from more recent international genocides in scope, timeframe, and lack of termination. The second objective is to outline the psychological and cultural damage done by contemporary racism, slavery's legacy. The final objective is to suggest a strategy to lessen racism in the US and to begin, at long last, reconciliation and healing from the effects of slavery and Indian genocides.

\section{American Genocides}

Raphaël Lemkin, who defined the concept of genocide before it became a legal concept, studied several histories as part of his background research. ${ }^{5}$ Two of these histories were of Native peoples in the Americas and the actions of European colonists against Africans. His definition of genocide is derived from these and other histories and is intended to describe actions that targeted groups of people, rather than individuals. Genocide is not about acts against individuals or groups of individuals. Lemkin defined genocide as acts against racial, religious, political, and other social groups. Genocide covers acts against group membership -i.e., Jews, Armenians, Bosnians, and Native Americans. According to Lemkin, the objective of genocidal acts is to destroy a group of people, in whole or in part. The UN General Assembly, in its 55th session, adopted Lemkin's definition of Genocide and list of acts as genocidal crimes. What they added was a clause making genocide a crime if intent could be demonstrated as well. In exploring Lemkin's guidance, it is not our intent to address the international legal definitions and jurisprudence regarding genocide as a crime; they are addressed elsewhere. ${ }^{6}$

\section{Slavery as Genocide}

In interpreting Lemkin, the case for the charge of genocide for slavery in the US is as follows.7 Africans were forbidden to speak their languages, use their African names, practice their religions, or maintain their native cultures; in effect, they were stripped for their African "national, ethnical, and religious group" identities. This is the destruction of what made them African, and of their culture "as a whole or in part." 8 Enslaved Africans for generations after their initial arrivals were killed for disobeying or defying their masters, opposing slavery, stealing food, or for running away; this is the first of Lemkin's genocidal charges. For generations, they were starved, physically exposed by lack of clothing, over-worked, tortured, and raped; this is the second genocidal charge in which survivors were physically and bodily harmed. Before African women were imported, enslaved African men were prevented from forming African families. In effect, measures (were imposed) to prevent births within the group; this is the fourth genocidal charge. Finally, in the fifth genocidal charge, there was forcible transfer of children from their parents and community of origin. Throughout slavery in the US, the children of enslaved Africans were sold as chattel. Slavery could not have been sustained without committing these genocidal acts.

\footnotetext{
4 There are now clear psychological, health, and mortality costs to Whites for racism; see Jonathan M. Metzl, Dying of Whiteness: How the Politics of Racial Resentment Is Killing America's Heartland (New York: Basic Books, 2019).

5 “Three Responses to 'Can There Be Genocide Without the Intent to Commit Genocide?,'” Journal of Genocide Research 10, no. 1 (2008), 111-133.

${ }^{6}$ Willian A. Schabas, Genocide in International Law: The Crimes of Crimes (New York: Cambridge University Press, 2000).

7 The same case can be made for all other Western nations that were the recipients of enslaved Africans.

8 United Nations, General Assembly Resolution 260, Convention on the Prevention and Punishment of the Crime of Genocide, December 9, 1948 (UN Doc. A/RES/260(III)).
} 


\section{Intent among Slavers}

We can even consider Article II of the UN Convention on genocide; it stipulates that the above acts were genocidal and potentially criminal only if it can be shown that the perpetrators acted intentionally - that perpetrators knew the effects of their actions. ${ }^{9}$ The fact is: Slavers were very much aware of the outcomes of their activities. The problem with intent in African slavery is that slavers knowledge of the effects of their actions against Africans did not matter. As long as Africans were considered inferior to Europeans, whatever slave-masters did were considered an improvement of Africans' original condition. Any physical and mental suffering Africans experienced was for their own good and was an outcome of their inferiority-precisely as many White Americans believe today. Enslavers and slave masters did not see their actions as criminal; they were quite the opposite-necessary, moral, and even blessed by God.

Philip Livingston wrote in 1750 that "the slave trade was a way of "redeeming an unhappy people from inconceivable misery.'"10 Gérard Mellier, mayor of Nantes, wrote about the same time, "At bottom, the blacks are naturally inclined to theft, robbery, idleness, and treason. In general, they are suited only to live in servitude and for the work and the agriculture of our colonies."11 The intent was clear, and the outcome justified when a slave master found his runaway slave on an 1839 Vicksburg street and shoot him dead. When questioned, the man explained that it was his runaway nigger. This explanation satisfied everyone. The slave master was in his rights to kill his slave under such circumstances as if the slave had been a dog or other escaped animal; 12 there was no difference. African inferiority was a given, so, there was no need to even write about it and dwell on the obvious.

Furthermore, the traumatization of slaves was practiced, refined, and intentional. How to beat, abuse, torture, publicly humiliate, and terrorize slaves to control and motivate them to obey and work were the basis of endless discussion, exchange, consultation, and advisement among slave masters. ${ }^{13}$ Managing slaves was an art passed on to new masters and overseers from one generation to the next. Slave masters' intent regarding their actions toward their slaves was quite clear.

\section{Elimination of Native People as Genocide}

There were an estimated two million Native peoples in North America (not including Canada) when Columbus arrived. ${ }^{14}$ By 1890, from 150,000 to 237,000 remained, or eight to twelve percent of the 1492 population. By Raphaël Lemkin's definition, it is virtually self-evident that Native American ethnic groups, in what is now the US, were destroyed "as a whole or in part" after contact with the British and Americans. Denial of Indian genocide is centered in the view that the vast majority of Native Americans died from diseases. ${ }^{15}$ According to this narrative, Indian deaths were caused by a regrettable flaw in Indian immunities, a misfortune for which European settlers were not responsible. The fact that European settlers brought diseases to North America is somehow unrelated to Indian deaths, and settlers' unwelcomed presence and

\footnotetext{
${ }^{9}$ Devrim Aydin, "The Interpretation of Genocidal Intent Under the Genocide Convention and the Jurisprudence of International Courts," The Journal of Criminal Law 78, no. 5 (2014), 423-441.

${ }^{10}$ Hugh Thomas, The Slave Trade: The Story of the Atlantic Slave Trade: 1440-1870 (New York: Simon and Schuster, 1997), 302.

11 Ibid.

12 Joseph Henry, A Statement of Facts Respecting the Condition and Treatment of Slaves in the City of Vicksburgh and its Vicinity, in the State of Mississippi, in 1838 and 1839 (Washington, D.C.: Library of Congress, 1839), accessed November 13, 2021, https:// lccn.loc.gov/10034478.

13 James O. Breeden, ed., Advice Among Masters: The Ideal in Slave Management in the Old South (Westport: Greenwood Press, 1980).

14 Russell Thornton, American Indian Holocaust and Survival: A Population History Since 1492 (Norman: University of Oklahoma Press, 1987), 42; Ward Churchill, A Little Matter of Genocide: Holocaust and Denial in the Americas 1492 to the Present (San Francisco: City Lights Books, 1997)

15 Noble David Cook, Born to Die Disease and New World Conquest, 1492-1650 (New York: Cambridge University Press, 1998).
} 
theft of Indian lands are somehow irrelevant. Today, 345 Native American tribes, nations, and bands survive and are now officially recognized by the US federal government as Native Americans. ${ }^{16}$ There are another 229 groups in Alaska and other survivors that are forgotten as Indians and not recognized by either State or Federal governments. ${ }^{17}$

Reviews of the few available tribal histories paint a different picture then death by disease. There was a pattern to Indian genocide.18 One-by-one, each Native state was defeated militarily; successive Native generations fought and were defeated as well. As settlers became more numerous and stronger militarily, Indians became fewer and weaker militarily. In one Indian nation after the other, resistance eventually collapsed due to the death toll from violence. Then, survivors were displaced from their ancestral lands, which had sustained them for generations. Once survivors were sufficiently impoverished, disorganized, and defenseless, their remaining villages were burned, and food sources destroyed. In the final stage of elimination, they were hunted, killed for sport, scalped, hung, raped, and abused in whatever way settlers desired. There are virtually no local US histories without a record of Indian massacres. ${ }^{19}$ Starting in 1830, surviving Native people, mostly Cherokee, in the Eastern US were ordered by President Andrew Jackson to march up to two thousand miles and to cross the Mississippi River to settle in Oklahoma. Thousands died on the Trail of Tears. ${ }^{20}$ This pattern of defeat, displacement, and victimization repeated itself in the American West.

From this history, Native Americans were victims of all five Lemkin specified genocidal acts. ${ }^{21}$ Members of each group were killed not as individuals, but because they were Indians (act one). Once they could no longer resist, serious bodily and mental harm was done to survivors (act two). Once they were confined to reservations, they were made dependent on the Bureau of Indian Affairs for food, housing, education, and healthcare. The Bureau's neglect inflicted on the group conditions of life calculated to bring about its physical destruction in whole or in part (act three). There was the forcible transfer of children away from their parents and community of origin; Indian children were taken from their families and put in Indian Schools to destroy their culture and identities as Indians 22 (act five).

\section{Intent against Indians}

As with slavery, there are case-by-case narratives of settler statements and government records of contact with Native peoples that made three things clear. Settlers and colonial, municipal, state, and federal governments wanted Native lands, and Indians did not give up their land without a fight. Peace for settlers and unchallenged access to Native land required eliminating the Native presence. There is no need to go far to find knowledge of this murderous intent. One can start with US Presidents. The third President of the US, Thomas Jefferson, said, "If ever we are constrained to lift the hatchet against any tribe, we will never lay it down till that tribe is exterminated, or driven beyond the Mississippi... in war, they will kill some of us; we shall destroy them all." 23 President Andrew Jackson in ordering the trail of tears, said:

16 Alexa Koenig and Jonathan Stein, "Federalism and the State Recognition of Native American Tribes: A Survey of State-Recognized Tribes and State Recognition Processes Across the United States," Santa Clara Law Review 48, no. 1 (2007), 79-153.

17 Mark Edwin Miller, Forgotten Tribes: Unrecognized Indians and the Federal Acknowledgment Process (Lincoln: University of Nebraska Press, 2004).

${ }_{18}$ Gary Clayton Anderson, Ethnic Cleansing and the Indian: The Crime That Should Haunt America (Norman: University of Oklahoma Press, 2014)

${ }_{19}$ Alex Alvarez, Native America and the Question of Genocide (Lanham: Rowman and Littlefield, 2014).

${ }^{20}$ Julia Coates, Trail of Tears (Santa Barbara: Greenwood, 2014).

${ }^{21}$ Alvarez, Native America.

22 David Wallace Adams, Education for Extinction: American Indians and the Boarding School Experience, 1875-1928 (Lawrence: University Press of Kansas, 1995).

${ }^{23}$ Levi Rickert, "US Presidents in Their Own Words Concerning American Indians," Native News Online, February 15, 2021, accessed June 3, 2021, https:/ / nativenewsonline.net/currents/us-presidents-in-their-own-words-concerningamerican-indians 
My original convictions upon this subject have been confirmed by the course of events for several years, and experience is every day adding to their strength. That those tribes cannot exist surrounded by our settlements and in continual contact with our citizens is certain. They have neither the intelligence, the industry, the moral habits, nor the desire of improvement, which are essential to any favorable change in their condition. Established in the midst of another and a superior race, and without appreciating the causes of their inferiority or seeking to control them, they must necessarily yield to the force of circumstances and ere long disappear. ${ }^{24}$

From the 1860s through 1900, the popular mantra for killing Indians, attributed to General Philip Sheridan who fought Indians after the Civil War, was "the only good Indian is a dead Indian"25 _ an often-repeated statement well into the last century. There is virtually no evidence that most Native peoples died due to diseases, leaving vast tracks of North America open to unfettered settler access.

After meeting Raphaël Lemkin's criteria for genocide, slavery, and the elimination of Native peoples in the US also meet social science or structural criteria for genocide that reiterate the same acts. These include definitions by Pieter Drost, Irving Louis Horowitz, Henry Hutterbach, Steven Katz, Helen Fein, Frank Chalk, and Kurt Jonassohn, Jennifer Balint, and Israel Charny. ${ }^{26}$

What makes the enslavement of Africans and the elimination of Native people in the Western Hemisphere distinct from other modern genocides is the enormity of both potential acts. The number of people killed and displaced, and the number of cultures destroyed on two continents are unprecedented. Genocidal acts in both cases went on for over four hundred years. These long-term genocides meant that Africans and Native people experienced numerous genocidal acts over generations. Furthermore, this long genocidal period since the 1500s led to a unique development among European settlers who executed these acts and needed to justify them-the belief that Europeans were culturally and biological superior (racism) to Africans and other people of color. ${ }^{27}$ The American version of racism that framed slavery in the American South and the elimination of Native people is today influential worldwide. ${ }^{28}$ The racist legacy of slavery and Native elimination make these genocides effectively open-ended psychological and cultural phenomena-they have not ended.

\section{Damage Done by Slavery and Native Genocides}

Slavery: Five things were done intentionally to damage enslaved Africans psychologically. ${ }^{29}$ First, they were beaten, tortured, and humiliated as warnings to all others of what would happen to them if any slave challenged or questioned their enslavement. They were abused with enough brutality to maintain constant fear of violent punishment. Second, slaves had

\footnotetext{
${ }^{24}$ Ibid.

${ }^{25}$ Wolfgang Mieder, “'The Only Good Indian Is a Dead Indian:' History and Meaning of a Proverbial Stereotype," The Journal of American Folklore 106, no. 419 (1993), 38-60.

${ }^{26}$ Colin Tatz, With Intent to Destroy: Reflecting on Genocide (London: Verso, 2003).

27 St. Clair Drake, Black Folk Here and There (Los Angeles: Center for Afro-American Studies, UCLA, 1987); Winthrop D. Jordan, White Over Black: American Attitudes Toward the Negro, 1550-1812, 2nd. ed. (Chapel Hill: The University of North Carolina Press, 1968).

${ }^{28}$ Alden T. Vaughan, ed., Roots of American Racism: Essays on the Colonial Experience (New York: Oxford University Press, 1995).

29 Benjamin P. Bowser, "An Exploration of the Psychological Legacy of Slavery: Case of the U.S," in The Psychological Legacy of Slavery in the Western Hemisphere, ed. Benjamin P. Bowser and Aimé Charles-Nicolas (Jefferson: McFarland Publishing, 2021).
} 
to be made to feel that they were powerless to stop or avoid the beatings, rapes, torture, and humiliation. Third, physical deprivation kept slaves' attention fixed on momentary survival. This left them with little opportunity to ponder or plan resistance or escape and degraded their ability to successfully flee and survive if they escaped. Fourth, it was necessary to create total dependence among slaves on their masters and overseers. The more dependent they were in fact and mind, the greater was their powerlessness, the more immobilizing was fear of violence and sense of powerlessness. Finally, even if they had intimate relationships with their masters, they always needed to be aware that their slave master could unleash unspeakable violence against them.

The five conditions that psychologically damaged slaves were identical to the oppression used in World War II concentration camps. In both cases, slaves and camp inmates were intentionally and repeatedly traumatized to maintain compliance, order, and control. For camp inmates or slaves, their oppression became internalized and expressed through violence directed at one another, fearfulness, high anxiety, anger, deep depression, assimilation of a (racial) sense of inferiority, and child abuse and neglect. ${ }^{30}$ These outcomes are precisely the International Classification of Mental and Behavioral Disorders (ICD-10) symptoms for psychic trauma. ${ }^{31}$ However, trauma symptoms for slaves are distinct from concentration camp inmates in one way. Instead of being an outcome for several events or several years of trauma, slaves experienced traumatization over a lifetime, as did their children and children's children. Abuse and trauma went on long enough and occurred frequently enough for post-traumatic stress disorder (PTSD) to become intrinsic to African American culture. ${ }^{32}$ Slavery was a multi-generational holocaust.

Native Genocide: The present-day behavioral outcomes of Native American elimination are high rates of suicide, alcoholism, drug abuse, domestic violence, depression, anger, child abuse, and self and other disdain. ${ }^{33}$ These outcomes are also consistent with the ICD-10 symptoms for psychic trauma. ${ }^{34}$ As with enslaved Africans, the ICD-10 does not diagnose psychic traumas that have gone on repeatedly within and across generations. Tribal survivors, most of whom are on US Western reservations, have selective memories of their ritual, beliefs, and customs. Many are now re-imagining their culture, reconstructing rituals, and are making efforts to preserve their remaining languages.

Both African and native American survivors have evolved resilient subcultures from remnants of their original cultures. However, symptoms of PTSD experienced in genocide across generations have also become part of their ethnic cultures ${ }^{35}$ and are reinforced now by present-day racism. ${ }^{36}$ Can anything be done to reduce racism as one of the psychological legacies of African slavery and the elimination of Native Americans, and reverse generations of PTSD?

\footnotetext{
30 Joy DeGruy Leary, Post Traumatic Slave Syndrome: America's Legacy of Enduring Injury and Healing (Milwaukie: Uptone Press, 2005).

31 World Health Organization (WHO), The ICD-10 Classification of Mental and Behavioural Disorders: Clinical Descriptions and Diagnostic Guidelines (Geneva: World Health Organization, 1992).

32 Ron Eyerman, Cultural Trauma: Slavery and the Formation of African American Identity (New York: Cambridge University Press, 2001).

33 Eduardo Duran and Bonnie Duran, Native American Postcolonial Psychology (Albany: State University of New York Press, 1995).

${ }^{34} \mathrm{WHO}$, The ICD-10 Classification.

35 Shelly A. Wiechelt et al., "Cultural and Historical Trauma among Native Americans," in Trauma: Contemporary Directions in Theory, Practice, and Research, ed. Shoshana Ringel and Jerrold R. Brandell (Thousand Oaks: Sage Publications, 2012).

36 DeGruy, Post Traumatic Slave Syndrome.
} 


\section{Toward Reconciliation and Healing}

Three closely related steps can be taken to move the US toward reconciliation and healing. ${ }^{37}$ First, individuals can be healed while structural change is sought. The second step is for institutional reform. However, a lesson learned from decades of domestic efforts is that improvements in individual and institution outcomes cannot be sustained without also challenging the cultural beliefs that reinforce institutional practices and individual disdain for others. ${ }^{38}$ So, in the US, the third step requires addressing racism at its cultural core. We hypothesize that through simultaneous efforts to reduce both institutional and cultural racism, a point can be reached where some real acknowledgment of the damage done by African and Native American genocides will be possible.

\section{Healing Individuals}

Counseling Native Americans

In response to high rates of suicide, homicide, alcoholism, domestic violence, and child abuse, psychological counseling has been provided to Native people in a variety of settingscommunities, prisons, schools, and individually. To date, these treatment outcomes have been disappointing. ${ }^{39}$ The problem is that Western-based therapeutic approaches presume the patients' psychological problems are individual in origin and can be addressed as such. However, there is increasing recognition among therapists that patient-centered approaches ignore the historical and social causes of psychological dysfunction among Native peoples. Brave Heart et al. and Duran et al. have brought attention to the role of culturally embedded historical trauma (HT) in alcohol and other drug use among Native peoples in the US and Canada. ${ }^{40}$ Gone re-frames current Native American distress to the intergenerational effects of massive group oppression. ${ }^{41}$ In effect, individual drug and alcohol use are enduring outcomes of HT.

Native People suffer from historically unresolved grief as well as trauma. The specifics of lost relatives, land, culture, and identity are well known to Indian people. Psychological interventions to address Native people's unresolved grief and trauma must include American Indian approaches to address cultural damage. Duran et al. propose addressing the impact of HT through religious and family ceremonies, which explicitly link current functioning to the sequelae of HT.42 Evidence is provided for the effectiveness of such approaches. Brave Heart et al. describe healing the "soul wound" with psycho-educational group interventions. ${ }^{43}$ Gone describes a community-based intervention for healing HT. ${ }^{44}$ A review of such interventions in the US, Canada, Australia, and New Zealand by Gameon and

\footnotetext{
37 Bennett Collins and Alison Watson, "Examining the Potential for an American Truth and Reconciliation Commission," Carnegie Ethics Online Monthly Column, February 5, 2015, accessed January 4, 2020, https:// www.carnegiecouncil.org/publications/ethics online/0102.

38 Judy Carter et al., eds., Regional and Ethnic Conflicts: Perspectives from the Front Lines (New York: Routledge, 2008).

39 U.S. Office of the Surgeon General, "Mental Health Care for American Indians and Alaska Natives," in Mental Health: Culture, Race, and Ethnicity: A Supplement to Mental Health: A Report of the Surgeon General, ed. U.S. Office of the Surgeon General (Rockville: US Department of Health and Human Services, 2001).

40 Eduardo Duran et al., "Healing the American Indian Soul Wound," in International Handbook of Multigenerational Legacies of Trauma, ed. Yael Danieli (New York: Plenum Press, 1998); Maria Yellow Horse Brave Heart et al., "Historical Trauma Among Indigenous Peoples of the Americas: Concepts, Research, and Clinical Considerations," Journal of Psychoactive Drugs 43, no. 4 (2011), 282-290.

${ }^{41}$ Joseph P. Gone, "Reconsidering American Indian Historical Trauma: Lessons from an Early Gros Ventre War Narrative," Transcult Psychiatry 51, no. 3 (2014), 387-406.

42 Duran et al., Healing the American Indian Soul Wound.

${ }^{43}$ Brave Heart et al., Historical Trauma.

${ }^{44}$ Joseph P. Gone, "A Community-Based Treatment for Native American Historical Trauma: Prospects for EvidenceBased Practice," Journal of Consulting and Clinical Psychology 77, no. 4 (2009), 751-762.
} 
Skewes describes ten interventions using Native people's community-based approaches. ${ }^{45}$ However, the drawback to individual psychological and cultural therapies is that they cannot stop ongoing psychological assaults from racial discrimination and social rejection derived from racism. These therapeutic efforts address damage only to individuals.

\section{Counseling African Americans}

The intergenerational transmission of HT among African-Americans has received scant attention among US health researchers. ${ }^{46}$ What has been found are links between current racial discrimination and substance use and abuse among African-American youth. ${ }^{47}$ With controls for education and income, those who report experiencing racial discrimination were found to have 3.31 higher odds of elevated drug use. Clark found experiencing racial bias is linked to depressive symptoms and substance use among African Americans and African Caribbean 18 to 35-year-olds. ${ }^{48}$ Metzger et al. found that the stress associated with racial discrimination was linked to alcohol use and binge drinking. ${ }^{49}$ Carliner et al. found that perceived racial discrimination correlates to a 2.32 higher risk of illicit drug use among a sample of 6,587 African-American adults. ${ }^{50}$ Each outcome is an effect of current racial discrimination. None of these outcomes have been linked to HT.

However, perceived racial discrimination does not explain black-on-black violence, low evaluation of personal worth, self and other hatred, domestic violence, and depression. Nor does racial discrimination explain beating and traumatizing children to compel obedience, and frequent reference to one another as "niggers" and to African American women as "bitches." 51 Also, there is active denial and unconscious shame over having gone through slavery, and of being black. ${ }^{52}$ These are behaviors where HT can be demonstrated. Furthermore, over 4,000 lynchings during Jim Crow (1890-1960) reinforced HT from slavery and led to the first petition to the UN for relief from genocide. ${ }^{53}$ Since then, police, mob, and individual acts of racial violence have only compounded unresolved HT from slavery. Joy DeGruy explains these unaddressed issues among African Americans as a post-traumatic slave syndrome. ${ }^{44}$ The syndrome has existed across generations since slavery. It has gone unacknowledged, untreated, unresolved, and denied with tragic consequences.

45 Julie. A. Gameon and Monica C. Skewes, "A Systematic Review of Trauma Interventions in Native Communities," American Journal of Community Psychology 65, no. 1-2 (2019), 223-241.

${ }^{46}$ Farzana T. Saleem et al., "Addressing the 'Myth' of Racial Trauma: Developmental and Ecological Considerations for Youth of Color," Clinical Child and Family Psychology Review 23, no. 1 (Mar 2020) 1-14; Erica J. Wilkins et al., "Residual Effects of Slavery: What Clinicians Need to Know," Contemporary Family Therapy 35, no. 1 (2013), 14-28.

47 Frederik X. Gibbons et al., "Early Experience with Racial Discrimination and Conduct Disorder as Predictors of Subsequent Drug Use: A Critical Period Hypothesis," Drug and Alcohol Dependence 88 Suppl. 1 (2007) S27-S37; Luisa N. Borrell et al., "Self-Reported Racial Discrimination and Substance Use in the Coronary Artery Risk Development in Adults Study," American Journal of Epidemiology. 166, no. 9 (2007) 1068-1079.

48 Trenette T. Clark, "Perceived Discrimination, Depressive Symptoms, and Substance Use in Young Adulthood," Addictive Behaviors. 39, no. 6 (2014), 1021-1025.

${ }^{49}$ Isha W. Metzger et al., "African American Emerging Adults' Experiences with Racial Discrimination and Drinking Habits: The Moderating Roles of Perceived Stress," Cultural Diversity and Ethnic Minority Psychology 24, no. 4 (2018), 489-497.

${ }^{50}$ Hannah Carliner et al., "Racial Discrimination, Socioeconomic Position, and Illicit Drug Use Among US Blacks," Social Psychiatry \& Psychiatric Epidemiology 51, no. 4 (2016), 551-560.

${ }^{51}$ Benjamin P. Bowser, Gangster Rap and Its Social Cost: Exploiting Hip Hop and Using Racial Stereotypes to Entertain America (Amherst: Cambria Press, 2012); DeGruy, Post Traumatic Slave Syndrome.

52 Aimé Charles-Nicolas, "A Psychiatric Look at the Legacy of Slavery," in The Psychological Legacy of Slavery in the Western Hemisphere, ed. Benjamin Bowser and Aimé Charles-Nicolas (Jefferson: McFarland Publishers, 2021).

53 William Patterson, ed., We Charge Genocide: The Crime of Government Against the Negro People (New York: International Publishers, 1970)

${ }^{54}$ DeGruy, Post Traumatic Slave Syndrome. 
In African American communities, there is virtually no community-wide psychological treatment. Federal and state community mental health centers and psychotherapy were defunded decades ago. ${ }^{55}$ Where treatment exists, outcomes for African Americans are also poor and vary by socioeconomic background. ${ }^{56}$ Again, it is assumed that African American patients' psychological problems are individual in origin and can be addressed as such. As with Native Americans, psychotherapists inadvertently end up trying to treat personal issues that have institutional and cultural roots.

Efforts to develop effective treatments are underway via religious-based African American organizations. The goal is to address intergenerational transmission of HT on current family functioning, attitudes toward self-worth, and interpersonal violence aimed at other African Americans-the cultural transmission of trauma. ${ }^{57}$ Such a program is described by Myers and exists in New York City. ${ }^{58}$ The Association of Black Psychologists has proposed Emotional Emancipation Circles in partnership with Community Healing Networks as a possibility. 59

\section{Counseling White Americans}

To move the US toward acknowledging its dual genocides requires getting White Americans to understand their role in denying these genocides, and in justifying continued racism. Racism should be included as an antisocial personality disorder or sociopathy in the American Psychiatric Association Diagnostic and Statistical Manual (DSM). ${ }^{60}$ Attempts by Black psychiatrists to have racism addressed as a psychiatric issue have been rebuffed by the white mainstream American Psychiatric Association (APA). The reason for the APA's opposition to including racism in the DSM is that racism is culturally normative. If racism were included in the DSM, it would be considered sociopathic behavior, which refers to a cluster of symptoms that describes people who, based on environmental influences, display a callous disregard (lack of empathy) towards others. Because of a weakened conscience, they behave recklessly, aggressively, or in a wholly indifferent manner towards the needs and humanity of others, even when they know their behavior is wrong. ${ }^{61}$ Racism disposes some Whites to act in this way toward people of color, and to treat them as they would not treat other Whites.

At the individual level, addressing beliefs in white racial supremacy should be integrated into psychotherapy and counseling for White Americans. Exploring historical and unresolved grief and trauma may be an intergenerational issue for White Americans as well. HT and grief may be related in some way to a need for a strong belief in white supremacy. The failure of the APA to address racism and the psychology of white supremacy means the association is unwilling to address one of the fundamental psychiatric and cultural problems of our times. However, even if the DSM was revised to include white supremacy and White Americans were counseled about racism, these measures would be insufficient to eliminate racism in the US. As with Native and African Americans, White psychotherapy will

\footnotetext{
55 Peter Cunningham et al., "The Struggle To Provide Community-Based Care To Low-Income People With Serious Mental Illnesses," Health Affairs 25, no. 3 (2006), 694-705.

${ }^{56}$ Brendon Saloner and Benjamin Lê Cook, "Blacks And Hispanics Are Less Likely Than Whites To Complete Addiction Treatment, Largely Due To Socioeconomic Factors," Health Affairs 32, no. 1 (2013), 135-145.

57 Eyerman, Cultural Trauma.

${ }^{58}$ Rebecca S. Myers, Healing the Disaster of Slavery: The Maafa Suite at St. Paul's Community Baptist Church (Brooklyn: New York, 2014).

59 Taasogle Daryl Rowe and Kamilah Marie Woodson, "How to Heal the African American Community," The Conversation, June 19, 2010, accessed June 25, 2020, https:/ theconversation.com/how-to-heal-african-americanstraumatic-history-98298.

${ }^{60}$ American Psychiatric Association, Diagnostic and Statistical Manual of Mental Disorders (DSM-5), 5th ed. (Arlington: American Psychiatric Association, 2013); Michael Puskar, "Sociopath Definition And Symptoms," Better Help, May 14, 2020, accessed June 25, 2020, https://www.betterhelp.com/advice/sociopathy/sociopath-definition-andsymptoms/.

61 American Psychiatric Association, Diagnostic and Statistical Manual.
} 
inadvertently end up addressing the problems of institutional and cultural racism as problems of individual pathology.

\section{Addressing Institutional Racism}

Effective change requires addressing institutional racism that consists of policies and practices which reinforce racial inequities in a nation's institutions-i.e., education, housing, government, employment, and religion. ${ }^{62}$ Direct and ongoing challenges to racist practices and policies by social and civil rights movements are essential. The civil rights movement of the 1950s and 1960s as well as Black Lives Matter today play these vital roles. A comparison between issues in two seminal reviews of race relations and inequality in American life between 1945 and 1989 show the long-term progressive effects of civil rights efforts. ${ }^{63}$ Perhaps, the next review will show the effects of the Black Lives Matters movement.

A strategically important institution with extraordinary potential to move the US toward acknowledging and then resolving its genocides and reducing racism are primary, secondary, and higher education. ${ }^{64}$ The American public needs to be educated about both the history of American genocides and the outcomes of these genocides in continued racism against Native and African Americans, and other people of color. A new UNESCO sponsored publication reviews how this is being done internationally with potential lessons for the US.65 Documentary films is another way to deploy such an education and have been a very effective educational medium for some time. ${ }^{66}$ Some programming already exists on issues related to African and Native American history and experiences. However, the variety and types of documentaries and feature programs need to be broadened. There is a need for documentary series on the transatlantic slave trade, slavery, and the genocide of Native peoples in the Western Hemisphere and the US.

There is a particular recommendation regarding the teaching of the transatlantic slave trade and slavery that should apply to teaching about the genocide of Native peoples as well. ${ }^{67}$ Primary and secondary school teachers are not trained to teach these subjects, and if these subjects are taught improperly, racists could be emboldened, and African and Native American students humiliated. Care must be taken in presenting such material, interpreting it, in guiding student reactions to it and responding to parent questions and complaints.

\section{Reducing Cultural Racism}

Attitudes, beliefs and values practiced over generations become part of the cultural fabric. In this way, racial inferiority and superiority (hierarchy) are the mental blueprints of expected outcomes regarding race-cultural racism. 68 Without a simultaneous reduction in cultural racism, any progress in reducing institutional and individual racism will be eroded in time. The

62 Shirley Jean Better, Institutional Racism: A Primer on Theory and Strategies for Social Change (Lanham: Rowman and Littlefield, 2008).

63 Gerald D Jaynes and Robin M. Williams, Jr., A Common Destiny: Blacks and American Society (Washington: National Academies Press, 1990), Gunnar Myrdal, An American Dilemma: The Negro Problem and Modern Democracy (New York: Harper and Row, 1962).

${ }^{64}$ Louk Hagendoorn and Shervin Nekuee, eds., Education and Racism: A Cross National Inventory of Positive Effects of Education on Ethnic Tolerance (New York: Routledge, 2018);. Elizabeth Vera et al., "Education Interventions for Reducing Racism," in The Cost of Racism for People of Color: Contextualizing Experiences of Discrimination, ed. Alvin N. Alvarez et al. (American Psychological Association, 2016), 295-316.

65 Paul E. Lovejoy and Benjamin P. Bowser, eds., The Transatlantic Slave Trade and Slavery: New Directions in Teaching and Learning (Trenton: Africa World Press, 2013); Wayne Journell, "An incomplete history: Representation of American Indians in State Social Studies Standards," Journal of American Indian Education 48, no. 2 (2009), 18-32.

${ }^{66}$ Roy P. Madsen, The Impact of Film: How Ideas Are Communicated through Cinema and Television (New York: Macmillan, 1973); Brian Winston et al., The Act of Documenting: Documentary Film in the 21st Century (London: Bloomsbury Publishing, 2018).

${ }^{67}$ Lovejoy and Bowser, The Transatlantic Slave Trade.

68 James Morris Blaut, “The Theory of Cultural Racism,” Antipode 24 no. 4 (1992), 289-299. 
most serious challenge to cultural racism now comes from scholars and activist exploring whiteness. ${ }^{69}$ Cultural racism sits squarely in white identity and as that identity is questioned and transformed so is cultural racism. Through civil rights, social movements, education, and challenges to whiteness, constituencies will evolve open to addressing American genocides. These constituencies can then be the basis of support for more direct efforts toward genocide acknowledgment and reconciliation. Strategic groups and activities can lead to broadening public support for acknowledgment and reconciliation of the American genocides. The following is a proposal for such a strategic approach based upon intergroup contact theory. ${ }^{70}$

\section{A Local Approach Proposal}

Lobbying the Federal government to acknowledge the American genocides and to act toward reconciliation might seem the most direct and appropriate course of action. With support from a few Representatives and Senators, a law can be proposed and, if passed, can achieve such an acknowledgment of genocide. Indeed, there are hundreds of non-governmental organizations (law firms, policy institutes, and lobby groups) in and near Washington, D.C., that are responsible for virtually every bill passed in Congress and all the provisions within each bill. However, this top-down approach to social change is increasingly out of touch with emerging public discontent with Congress and government. Furthermore, a legislative approach to genocide reconciliation would be seen by many as just another way for high paid lobbyists to make money. In this setting, if a law was passed as the first action to acknowledge the American genocides and to reconcile the damage, it would generate strong opposition and have minimal effect. Most importantly, it would not result in genuine national reconciliation even if the law survived its opposition.

An approach that is more consistent with the historical origins of racism in the US is to start from the bottom up at the county and then state levels, building local bases before pushing for change at the federal level of government. It was at the state and county levels of government where slavery was practiced and where Native Americans were hunted down and killed. The opposition of congressional representatives and senators to acknowledge genocide and their failure to address institutional racism (and a host of other problems) comes from people in the counties and states they represent. It is no coincidence that the most effective civil rights activism during the 1960s took place precisely at the county and state levels in the Deep South. This is where slavery was practiced and where Jim Crow laws were passed to deny the equal rights of African Americans, and where state-sanctioned violence was meted out to those who sought change and to vote. Likewise, the most effective Indian rights activism took place in the Dakotas, where the Native American presence is the strongest and where the genocides that defined present-day Native oppression took place. If one negates or blunts racism at the local level, and it will deflate racism at the federal level.

In the US, a resource that can be used to facilitate change is now conveniently available. The 1850 and 1860 web-based historical census records provide the identity of slave owners by county within Southern States. There are court, deed, probate, and tax records dating back to the inception of these counties that provide records of property sales, sales of slaves, taxation, and the settlement of estates. From the 1870 census (the first census after the emancipation of slaves), it is also possible to identify former slaves and to link them to their former owners from the 1860 census. Then groups of related slaves and owners can be traced forward in time through census and county records to the present. There are also records of original Native lands, the names of first settlers, the division of lands, and who held land titles to the present. The descendants of Native people and settlers who cleared the land can also be linked. It is at

\footnotetext{
${ }^{69}$ David R. Roediger, The Wages of Whiteness: Race and the Making of the American Working Class (London: Verso, 2007); Paula S. Rothenberg, ed., White Privilege: Essential Readings on the Other Side of Racism (New York: Worth Publishers, 2016).

70 Thomas F. Pettigrew et al., "Recent Advances in Intergroup Contact Theory," International Journal of Intercultural Relations 35 (2011), 271-280.
} 
this county level where we propose that genocide acknowledgment and reconciliation can begin. It is historically inaccurate and problematic to treat all African Americans and all Native Americans as an injured class and all White Americans as having perpetuated slavery. Not everyone who identifies today as African and Native Americans are descendants of the American genocides, and the majority of White Americans are descendants of immigrants who were not slave masters and arrived after slavery ended.

\section{Peer-to-Peer Resolution}

By working at the county level, we go directly and precisely to the heart of the denial of genocide, denial of responsibility for it, and shame and denial of slavery and Native American extermination. Bring the descendants of slave owners and settlers together with the descendants of enslaved Africans and Native people. These encounters can begin with two or three members of both sides. In a series of initial meetings, they can learn about one another, exchange information, learn about the history and circumstances that connect them and begin to address their interrelated strengths, denials, and family secrets. As dual-side leaders emerge, and as cross-group relationships develop, more family members on both sides can be encouraged to participate. If these encounters do not begin on-site where slavery was conducted, or where Native people were driven from the land, they should eventually gather there. Family members who have knowledge of their histories are ideal facilitators of these encounters. In cases where there are insufficient family knowledge and leaders to conduct such meetings, non-family facilitators will be necessary.

County-level slave-master or Native-settler pairs that work together have the potential to come to terms with their histories and devise appropriate contemporary responses that can lead to reconciliation. As of 2016, there are 3007 counties in the US and as many historical variations in slavery and Native genocide that could only be addressed accurately where these histories took place and among direct descendants. A few successful encounters and county truth and reconciliations can then serve as models and examples of authentic acknowledgment and reconciliation, which will encourage more dual-descendant encounters. A precedent already exists to such a process and is underway for a famous American family. Some descendants of the third President of the US, Thomas Jefferson, who drafted the US Constitution, agreed to DNA testing, and then acknowledged the descendants of Sally Hemming, the slave with whom Jefferson had a parallel, hidden, and slave family.71 Descendants of both lineages have met several times at the historic Jefferson estate, Monticello. This beginning could evolve into a more in-depth truth and reconciliation process for the Jefferson descendants. No one is keeping track of similar master-slave descendant gathering such as one that occurred recently in Prospect Hill, Mississippi. ${ }^{72}$ It is too early to know if such gatherings are effective reconciliation steps, since they are just starting.

If a critical mass of descendant encounters and shared relations evolve, state reconciliation associations can form to advocate for acknowledgment and reconciliation of the American genocides from the broader public. If the descendants of slave masters, enslaved Africans, settlers, and Native people can come together and confront racism, their histories, traumas, and guilt, why cannot the rest of the American public? This would be an excellent project for targeted private foundation support to increase the numbers of encounters and truth and reconciliations, to develop facilitators, and to show best practices in forming and facilitating such descendant gatherings. At some point, with enough experience, expertise, support, a national acknowledgment, and reconciliation of genocide will be feasible at the federal level.

\footnotetext{
71 Byron W. Woodson Sr., A President in the Family: Thomas Jefferson, Sally Hemings, and Thomas Woodson (Westport: Praeger, 2001).

72 Alan Huffman, “'This is Surreal:' Descendants of Slaves and Slaveowners Meet on US Plantation," The Guardian, November 16 2017, accessed June 25, 2020, https://www.theguardian.com/us-news/2017/nov/16/us-slaverydescendants-plantation-mississippi.
} 


\section{Reflection on Reparations}

Finally, local slavery and native genocide encounters can cut through another contentious issue, reparations.73 Arguments for financial compensation to individuals from the federal government have been made elsewhere. ${ }^{74}$ Another consideration is that local reconciliations can narrowly focus who should receive reparations, and what they should receive. It is imprecise that all African and all Native Americans should receive the same reparation and that all European Americans are equally liable. It is also problematic that the federal government is the only governmental unit held responsible, while the direct involvement of state and municipal governments in propagating slavery and Native genocide is ignored. Reparations could be refined and based on precise assessments of who did exactly what to whom. One does not have to look deeply into the history of slavery and Native elimination to realize that all enslaved Africans and Native peoples were not oppressed and traumatized in the same way and to the same degree. Current notions of reparation do not consider that our knowledge about slavery is based primarily on large plantation slavery while, at least in North Carolina, most slaves labored on small farms about which we still know very little. ${ }^{75}$ The elimination of Western plains' Indians took place in a relatively short time frame and was not nearly as thorough as that of Eastern Indians whose struggle started two hundred years earlier and who were subjected to the Trail of Tears.

Through local descendant reconciliation and healing, the descendants of perpetrators and victims can work out what would be the most appropriate reparation. Then reparations can be based upon their reconciliation and healing rather than some forced, imprecise, and imposed formula. Without direct descendants involved, reparations may neither fairly compensate the propriate descendants of victims nor have the descendants of those who committed genocide acknowledge their fore parents' actions. However, there is a critical pre-condition to any reparations that has not yet been met. The genocide of slavery and the elimination of Native people has not ended. Racism is the legacy of both genocides and must still to be confronted and dealt with. The cost of reparations is still mounting.

\section{Summary and Conclusion}

Slavery were acts of genocide, as was the elimination of Native peoples in the US. Both genocides meet Raphaël Lemkin and other social scientists' definitions of genocide. If pursued legally, both histories might also fulfill the UN Convention on Genocide's definition. However, a unique feature of both genocides is not addressed in any of the current genocide definitions. That is: Neither genocide ended. Slavery and the murder of Native people have been outlawed, yet the psychology and cultural basis for both genocides continue. After centuries, the belief in white racial supremacy (racism) has become embedded in American culture.

Acknowledging US genocides would mean accepting the psychological and cultural damage done to African and Native Americans. It would also mean that the nation must acknowledging the tolls that continuing racism is taking on both and has an obligation to do something about it. Healing individual African and Native Americans is possible. Counseling and various psychological therapies can work, providing that historical trauma and grief are dealt with in their communities as well. African and Native Americans' psychological problems have origins in culture and history rather than just in personality and individual experiences. However, for individual healing, one must learn to deal effectively with ongoing racism. Ultimately, lasting reconciliation of the American genocides will require lessening both institutional and cultural racisms. Such an effort should be undertaken best at the county and state levels rather than at the federal. If a few descendants of slaves and slave owners and Native Americans and the settlers met and eventually reconciled, it would be a powerful

\footnotetext{
${ }^{73}$ Randall Robinson, The Debt: What America Owes to Blacks Paperback (New York: Penguin Putnam, 2001).

74 Rashawn Ray and Andre M. Perry, "Why We Need Reparations for Black Americans," Policy 2020, Brookings Institute (Washington, D.C.: Brookings, 2020).

${ }^{75}$ Herbert G. Gutman, The Black Family in Slavery and Freedom, 1750-1925 (New York: Vintage Books, 1976).
} 
contradiction of cultural racism. It would also negate continued justifications of racism among Americans whose fore parents played no direct role in either genocide, but who unwittingly defend racism.

A lesson learned from World War II is that unacknowledged and unreconciled genocides are sources of future national and international conflicts and genocides. If this lesson is ignored, then unresolved genocides against enslaved Africans and Native people in the US are one of the most important unfinished businesses of the UN Convention on Genocide. The US is not exempt from the necessity to confront its genocidal history.

\section{Bibliography}

Adams, David Wallace. Education for Extinction: American Indians and the Boarding School Experience, 1875-1928. Lawrence: University Press of Kansas, 1995.

Allen, Theodore W. The Invention of the White Race. London: Verso, 1994.

Alvarez, Alex. Native America and the Question of Genocide. Lanham: Rowman and Littlefield, 2014.

American Anthropological Association. "AAA Statement on Race." American Association of Physical Anthropologists 101 (1996), 569-570.

American Psychiatric Association. Diagnostic and Statistical Manual of Mental Disorders, 5th ed. Arlington: American Psychiatric Association, 2013.

Anderson, Gary Clayton. Ethnic Cleansing and the Indian: The Crime That Should Haunt America. Norman: University of Oklahoma Press, 2014.

Aydin, Devrin. "The Interpretation of Genocidal Intent under the Genocide Convention and the Jurisprudence of International Courts." The Journal of Criminal Law 78, no. 5 (2014), 423441.

Better, Shirley Jean. Institutional Racism: A Primer on Theory and Strategies for Social Change. Lanham: Rowman and Littlefield, 2008.

Blaut, James Morris. “The Theory of Cultural Racism.” Antipode 24, no. 4 (1992), 289-299.

Borrell, Luisa N., David R. Jacobs, David R. Williams, Mark J. Pletcher, Thomas K. Houston, and Catarina I. Kiefe. "Self-Reported Racial Discrimination and Substance Use in the Coronary Artery Risk Development in Adults Study." American Journal of Epidemiology 166, no. 9 (2007), 1068-1079.

Bowser, Benjamin P. "An Exploration of the Psychological Legacy of Slavery: Case of the U.S." In The Psychological Legacy of Slavery in the Western Hemisphere, edited by Benjamin P. Bowser and Aimé Charles-Nicolas, 140-160. Jefferson: McFarland Publishing, 2021.

-------. Gangster Rap and Its Social Cost: Exploiting Hip Hop and Using Racial Stereotypes to Entertain America. Amherst: Cambria Press, 2012.

Brave Heart, Maria Yellow Horse, Josephine Chase, Jennifer Elkins, and Deborah B. Altschul. "Historical Trauma among Indigenous Peoples of the Americas: Concepts, Research, and Clinical Considerations." Journal of Psychoactive Drugs 43, no. 4 (2011), 282-290.

Breeden, James O., ed. Advice Among Masters: The Ideal in Slave Management in the Old South. Westport: Greenwood Press, 1980.

Carliner, Hannah, Erin Delker, David S. Fink, Katherine M. Keyes, and Daborah. S. Hasin. "Racial Discrimination, Socioeconomic Position, and Illicit Drug Use Among Us Blacks." Social Psychiatry \& Psychiatric Epidemiology 51, no. 4 (2016), 551-560.

Carmichael, Stokely and Charles Hamilton. Black Power: The Politics of Liberation in America. New York: Random House, 1967.

Carter, Judy, George Irani, and Vamik Volkan, eds. Regional and Ethnic Conflicts: Perspectives from the Front Lines. New York: Routledge, 2008.

Charles-Nicolas, Aimé. "A Psychiatric Look at the Legacy of Slavery." In The Psychological Legacy of Slavery in the Western Hemisphere, edited by Benjamin Bowser and Aimé CharlesNicolas, 98-116. Jefferson: McFarland Publishers, 2021.

Churchill, Ward. A Little Matter of Genocide: Holocaust and Denial in the Americas 1492 to the Present. San Francisco: City Lights Books, 1997. 
Clark, Trenette T. "Perceived Discrimination, Depressive Symptoms, and Substance Use in Young Adulthood." Addictive Behaviors 39, no. 6 (June 2014), 1021-1025.

Coates, Julia. Trail of Tears. Santa Barbara: Greenwood, 2014.

Collins, Bennett and Alison Watson. "Examining the Potential for an American Truth and Reconciliation Commission." Carnegie Ethics Online Monthly Column, February 5, 2015. Accessed January 4, 2020. https://www.carnegiecouncil.org/publications/ ethics online/0102.

Cook, Noble David. Born to Die Disease and New World Conquest, 1492-1650. New York: Cambridge University Press, 1998.

Cunningham, Peter, Kelly McKenzie, and Erin Fries Taylor. "The Struggle to Provide Community-Based Care to Low-Income People with Serious Mental Illnesses." Health Affairs 25, no. 3 (2006), 694-705.

DeGruy Leary, Joy. Post Traumatic Slave Syndrome: America's Legacy of Enduring Injury and Healing. Milwaukie, Oregon: Uptone Press, 2005.

Drake, St. Clair. Black Folk Here and There. Los Angeles: Center for Afro-American Studies, UCLA, 1987.

Duran, Eduardo, Bonnie Duran, Maria Yellow Horse Brave Heart, and Susan Yellow HorseDavis. "Healing the American Indian Soul Wound." In International Handbook of Multigenerational Legacies of Trauma, edited by Yael Danieli, 341-354. New York: Plenum Press, 1998.

Duran, Eduardo and Bonnie Duran. Native American Postcolonial Psychology. Albany: State University of New York Press, 1995.

Eyerman, Ron. Cultural Trauma: Slavery and the Formation of African American Identity. Cambridge: Cambridge University Press, 2001.

Gameon, Julie. A. and Monica C. Skewes. "A Systematic Review of Trauma Interventions in Native Communities." American Journal of Community Psychology 65, no. 1-2 (2019), 223-241.

Gibbons, Frederick X., Hsui-Chen Yeh, Meg Gerrard, Michael J. Cleveland, Carolyn Cutrona, Ronald L. Simons, and Gene H. Brody. "Early Experience with Racial Discrimination and Conduct Disorder as Predictors of Subsequent Drug Use: A Critical Period Hypothesis." Drug and Alcohol Dependency 88 Suppl. 1 (2007), S27-S37.

Gone, Joseph P. "A Community-Based Treatment for Native American Historical Trauma: Prospects for Evidence-Based Practice." Journal of Consulting and Clinical Psychology 77, no. 4 (2009), 751-762.

. "Reconsidering American Indian Historical Trauma: Lessons from an Early Gros Ventre War Narrative." Transcultural Psychiatry 51, no. 3 (2014), 387-406.

Gutman, Herbert G. The Black Family in Slavery and Freedom, 1750-1925. New York: Vintage Books, 1976.

Hagendoorn, Louk and Shervin Nekuee, eds. Education and Racism: A Cross National Inventory of Positive Effects of Education on Ethnic Tolerance. New York: Routledge, 2018.

Henry, Joseph. A Statement of Facts Respecting the Condition and Treatment of Slaves in the City of Vicksburgh and Its Vicinity, in the State of Mississippi, in 1838 and 1839. Washington, D.C.: Library of Congress, 1839.

Huffman, Alan. "'This Is Surreal:' Descendants of Slaves and Slaveowners Meet on Us Plantation." The Guardian, November 16 2017. Accessed June 25, 2020. https:// www.theguardian.com/us-news/2017/nov/16/us-slavery-descendants-plantationmississippi.

Jaynes, Gerald D. and Robin M. Williams, Jr. A Common Destiny: Blacks and American Society. Washington, D.C.: National Academies Press, 1990.

Jonathan, Metzl M. Dying of Whiteness: How the Politics of Racial Resentment Is Killing America's Heartland. New York: Basic Books, 2019.

Jordan, Winthrop D. White over Black: American Attitudes toward the Negro, 1550-1812, 2nd ed. Chapel Hill: The University of North Carolina Press, 1968. 
Journal of Genocide Research. "Three Responses to 'Can There Be Genocide without the Intent to Commit Genocide?."' Journal of Genocide Research 10, no. 1 (2008), 111-133.

Journell, Wayne. "An Incomplete History: Representation of American Indians in State Social Studies Standards." Journal of American Indian Education 48, no. 2 (2009), 18-32.

Koenig, Alexa, and Jonathan Stein. "Federalism and the State Recognition of Native American Tribes: A Survey of State-Recognized Tribes and State Recognition Processes across the United States." Santa Clara Law Review 48, no. 1 (2007), 79-153.

Lovejoy, Paul E. and Benjamin P. Bowser, eds. The Transatlantic Slave Trade and Slavery: New Directions in Teaching and Learning. Trenton: Africa World Press, 2013.

Madsen, Roy P. The Impact of Film: How Ideas Are Communicated through Cinema and Television. New York: Macmillan, 1973.

Metzger, Isha W., Temilola Salami, Sierra Carter, Colleen Halliday-Boykins, Riana Elyse Anderson, Maryam M. Jernigan, and Tiarney Ritchwood. "African American Emerging Adults' Experiences with Racial Discrimination and Drinking Habits: The Moderating Roles of Perceived Stress." Cultural Diversity in Ethnic Minority Psychology 24, no. 4 (2018), 489-497.

Mieder, Wolfgang. "'The Only Good Indian Is a Dead Indian:' History and Meaning of a Proverbial Stereotype." The Journal of American Folklore 106, no. 419 (1993), 38-60.

Miller, Mark Edwin. Forgotten Tribes: Unrecognized Indians and the Federal Acknowledgment Process. Lincoln: University of Nebraska Press, 2004.

Myers, Rebecca S. Healing the Disaster of Slavery: The Maafa Suite at St. Paul's Community Baptist Church. Brooklyn, New York, 2014.

Myrdal, Gunnar. An American Dilemma: The Negro Problem and Modern Democracy. New York: Harper and Row, 1962.

Patterson, William, ed. We Charge Genocide: The Crime of Government against the Negro People. New York: International Publishers, 1970.

Pettigrew, Thomas F., Linda R. Tropp, Ulrich Wagner, and Oliver Christ. "Recent Advances in Intergroup Contact Theory." International Journal of Intercultural Relations 35 (2011), 271280.

Puskar, Michael. "Sociopath Definition And Symptoms." Better Help, May 14, 2020. Accessed June 25, 2020. https://www.betterhelp.com/advice/sociopathy/sociopath-definitionand-symptoms/.

Ray, Rashawn and Andre M. Perry. "Why We Need Reparations for Black Americans." Policy 2020, Brookings Institute. Washington, D.C.: Brookings, 2020.

Rickert, Levi. "US Presidents in their own words concerning American Indians." Native News Online, February 15, 2021. Accessed June 3, 2021. https://nativenewsonline.net/ currents/us-presidents-in-their-own-words-concerning-american-indians.

Robinson, Randall. The Debt: What America Owes to Blacks Paperback. New York: Penguin Putnam, 2001.

Roediger, David R. The Wages of Whiteness: Race and the Making of the American Working Class. London: Verso, 2007.

Rothenberg, Paula S., ed. White Privilege: Essential Readings on the Other Side of Racism. New York: Worth Publishers, 2016.

Rowe, Taasogle Daryl and Kamilah Marie Woodson. "How to Heal the African American Community." The Conversation, June 19, 2010. Accessed June 25, 2020. https:// theconversation.com/how-to-heal-african-americans-traumatic-history-98298.

Saleem, Farzana T., Riana Elyse Anderson, and Monnica T. Williams. "Addressing the 'Myth' of Racial Trauma: Developmental and Ecological Considerations for Youth of Color." Clinical Child and Family Psychology Review 23, no. 1 (2020), 1-14.

Saloner, Brendon and Benjamin Lê Cook. "Blacks and Hispanics Are Less Likely Than Whites to Complete Addiction Treatment, Largely Due to Socioeconomic Factors." Health Affairs 32, no. 1 (2013), 135-145. 
Schabas, William A. Genocide in International Law: The Crimes of Crimes. New York: Cambridge University Press, 2000.

Tatz, Colin. With Intent to Destroy: Reflecting on Genocide. London: Verso, 2003.

Thomas, Hugh. The Slave Trade: The Story of the Atlantic Slave Trade: 1440-1870. New York: Simon and Schuster, 1997.

Thornton, Russell. American Indian Holocaust and Survival: A Population History Since 1492. Norman: University of Oklahoma Press, 1987.

U.S. Office of the Surgeon General. "Mental Health Care for American Indians and Alaska Natives." In Mental Health: Culture, Race, and Ethnicity: A Supplement to Mental Health: A Report of the Surgeon General, edited by the Office of the Surgeon General, 77-104. Rockville: U.S. Department of Health and Human Services, 2001.

United Nations. General Assembly Resolution 260, Convention on the Prevention and Punishment of the Crime of Genocide. December 9, 1948. UN Doc. A/RES/260(III).

Vaughan, Alden T., ed. Roots of American Racism: Essays on the Colonial Experience. New York: Oxford University Press, 1995.

Vera, Elizabeth, Daniel Camacho, Megan Polanin, and Manuel Salgado. "Education Interventions for Reducing Racism." In The Cost of Racism for People of Color: Contextualizing Experiences of Discrimination, edited by Alvin N. Alvarez, Christopher T. H. Liang, and Helen A. Neville, 295-316. American Psychological Association, 2016.

World Health Organization. The ICD-10 Classification of Mental and Behavioural Disorders. Geneva, Switzerland: World Health Organization, 1992.

Wiechelt, Shelly A., Jan Gryczynski and Kerry Hawk Lessard. "Cultural and Historical Trauma among Native Americans." In Trauma: Contemporary Directions in Theory, Practice, and Research, edited by Shoshana Ringel and Jerrold R. Brandell, 193-222. Thousand Oaks: Sage Publications, 2012.

Wilkins, Erica J., Jason B. Whiting, Marlene F. Watson, Jody M. Russon, and Allena M. Moncrief. "Residual Effects of Slavery: What Clinicians Need to Know." Contemporary Family Therapy 35, no. 1 (2013), 14-28.

Winston, Brian, Gail Vanstone, and Chi Wang. The Act of Documenting: Documentary Film in the 21st Century. London: Bloomsbury Publishing, 2018.

Woodson Sr., Byron W. A President in the Family: Thomas Jefferson, Sally Hemings, and Thomas Woodson. Westport: Praeger, 2001. 